\title{
The Effect of Strategic Planning Time and Task Complexity on L2 Written Accuracy
}

\author{
Asghar Salimi \\ University of Maragheh, Maragheh, Iran; \\ Department of English, Islamic Azad University, Urmia Branch, Urmia, Iran \\ Email: Asgharsalimi356@gmail.com \\ Parviz Alavinia \\ Faculty of Humanities and Letters, Urmia University, Valfajr 2 Blvd., Urmia, West Azerbaijan, Iran \\ Email: pevinia2006@yahoo.com \\ Parvin Hosseini \\ Department of English, Islamic Azad University, Urmia Branch, Urmia, Iran
}

\begin{abstract}
Over the past two decades, there has been a plethora of research attempting to find out the role of "task" in second and foreign language teaching and learning. A growing body of research in the past two decades has been devoted to the investigation of various aspects of task-based language teaching. A review of the studies conducted on various aspects of tasks reveled that there is a gap in the literature on the joint effects of task complexity and different types of planning time on $\mathrm{L} 2$ learners' oral and written performance. Therefore, the present study set out to investigate the effects of strategic pre-task planning and task complexity on L2 learners' written performance in terms of accuracy. To this end, 50 English language learners, both male and female, were chosen from an English language institute in Iran. A reliable valid task with simple and complex versions was used to collect written data from the participants. T-test was employed as the statistical means of analysis to compare the means of accuracy. The findings of the study revealed that pre-task strategic planning time in both simple and complex task led to more accuracy. The results of the study might carry significant implications for syllabus and task designers, language teachers in EFL/ESL contexts, and second language acquisition researchers.
\end{abstract}

Index Terms - task-based language teaching and learning, accuracy, planning time, strategic planning, task complexity

\section{INTRODUCTION}

Since 1990s, tasks have been the focus of attention as a unit of analysis both in language teaching and learning as well as syllabus design (Bygate, 2001; Gilabert, 2005, 2007; Ortega, 1995, 2005; Rahimpour, 2007, 2008; Robinson, 2005; Long, 2007). Task-based language teaching takes task as its unit of analysis and emphasizes the creation of meaning without any prior prescription of language forms. Therefore, learners are free to use any strategies or forms to perform the task and achieve the task goal (Willis and Willis, 2001).Research into task-based language teaching is mainly conducted because of dealing with the problem of determining the relevant grading and sequencing criteria for designing and classifying tasks for task-based syllabi (Long and Crookes, 1992; Robinson, 2003, 2006) and has mostly focused on investigating the effects of task design and task characteristics on task performance (Foster and Skehan, 1996; Skehan and Foster, 1997, 1999; Tavakoli and Foster, 2008; Tavakoli and Skehan, 2005). Tasked- based approaches to second language teaching focus on the ability of a learner to perform target-like without any explicit teaching of grammatical rules. According to Rahimpour (2010) TBLT is a response to a better understanding of language learning process.

In learning the second or foreign language, the learners may have some difficulties and these difficulties in learning the language might be reflected in the form of variations in the learners' oral or written performance. These variations in the performance of second or foreign language could be resulted from several factors. Tasks and their different features can have distinctive effects on L2 learners' both oral and written performance in terms of three linguistic domains of accuracy, fluency, and complexity. Task features are task structure, task condition, planning time, task complexity, and the generic features of the task. Among the task features which are hypothesized to be influential on the performance of L2 learners are planning time and its types, as well as task complexity. Planning time in task performance involves two main types pre-task planning and within-task planning. These two types of planning are simply distinguished in terms of when planning takes place. As the titles show in the first type, planning happens before the performance of task. In the second type, planning happens while the task is being performed. Also, pre-task planning itself is divided into two types namely rehearsal and strategic planning (Ellis, 2005). 
There have been many studies on the effect different task characteristics on L2 learners' oral and written performance (Ellis, 2005; Skehan and Foster, 1999; Rahimpour, 2008; Salimi and Yousefi, 2009; Dadashpour, 2011; Shafaei, 2012, Salimi et al, 2012; Salimi and Dadashpour, 2012a, 2012b). However, there have been few studies to investigate the effects of pre-task planning time and task complexity on L2 learners' oral/written performance. Thus, the present study set out to investigate the effects of strategic pre-task planning and task complexity on L2 learners' written performance in terms of accuracy.

\section{LITERATURE REVIEW}

\section{A. Task-based Language Teaching}

Task-based language teaching and learning has become an important area of research in second language research. Many scholars and researcher have investigated different aspects of TBLT (Ellis 2003, 2005, 2009; Foster and Skehan 1996, 1999; Long 1985, 2007; Long and Crooks 1992; Nunan 1989; Robinson 1995, 2001, 2007; Robinson and Gilabert 2007; Rahimpour, 2008, 2010; Skehan and Foster1999; Salimi and Dadashpour 2010, 2012; Mehrang and Rahimpour 2010; Tavakoli and Foster, 2008; Salimi et al, 2012). Task-based language teaching challenges the mainstream views about language teaching in that it is based on the fact that language learning will develop most successfully and effectively if teaching aims simply to create context and condition in which learners' natural language learning ability can be nurtured (Ellis, 2005).

According to Ellis (2009) TBLT is an approach for teaching second or foreign language that seeks to engage learners in interactionally authentic language use language by getting learners to perform a series of tasks. This approach aims to enable learners to acquire a new language system as well as to proceduralize their existing knowledge. In other words, this approach tries to force L2 learners to use their own linguistic resources to learn a new language.

\section{B. Planning Time}

Planning is an inseparable part of all spoken and written language use. That is, all speakers and writers need to decide what to say and write and how to do it (Ellis, 2005, p. 3). Planning time has been investigated in various studies on both first and second language production (Wigglesworth, 1997) and is assumed to be "an important feature of language production" (Sangarun, 2001, p. 6). Such studies have originated in L1 research aiming at developing cognitive models of oral production with planning as one of their components (Crookes, 1989). L1 research suggests that a number of features of L1 planned discourse would promote L2 development (Givon, 1979; Ochs, 1979).

In general, planning is considered as a goal-oriented mental activity that people are engaged in to achieve a particular objective (Newell and Simon, 1972). It involves the allocation of attentional resources and the regulation of cognitive processes (Yuan, 2001). Das, Kar, and Parilla (1996) define planning as follows "[planning] is oriented to the future, and may include the creation and selection of problems, as well as the anticipation of a sequence of actions to solve them (p.54)."

Planning has been associated with interlanguage development. Ellis (1987) was the first to propose that planning allows the learner to access the linguistic forms that have not yet been fully automated. Later, Crookes (1989) proposed that planning stretches IL and engages L2 acquisition processes. Moreover, Skehan (1996) proposed that planning, particularly L2 task planning frees up attentional resources and redirects them toward a focus on form.

\section{Types of Task Planning}

Ellis (2005, p. 3) distinguishes between two principal types of task planning. The distinction is in terms of when planning takes place. The first type of planning is pre-task planning which refers to planning that takes place before performing the task. It involves what Schmidt (2001) calls 'prepatory attention' that helps in performing actions with greater accuracy and speed. The second type is within-task planning which refers to planning that takes place while performing the task. Each of these two types is divided into two other types.

Pre-task planning is divided into rehearsal and strategic planning. In rehearsal, learners are given the opportunity to "perform the task before the 'main performance" (Ellis, 2005, p. 3). That is, the performance of the task for the first time is regarded as a preparation for the main and final performance. On the other hand, strategic planning which is the focus of the present study entails learners' preparation of the content of the task they will perform. In this type of planning, they "have access to the actual task materials" (Ellis, 2005, p. 3).

Within-task planning is also divided into pressured and unpressured planning. In pressured within-task planning, learners are usually not provided with enough time to plan on-line, while in unpressured within-task planning they are given enough time to plan on-line.

\section{Planning Time Studies}

Many studies have been conducted to investigate different types of planning time and their effects on L2 learners' oral and written task performance in terms of accuracy, fluency, and complexity (Foster and Skehan, 1996; Ortega, 1999; Yuan and Ellis, 2003; Sangarun, 2005; Tavakoli and Skehan, 2005; Mehrang and Rahimpour, 2010). Yuan and Ellis (2003) studied the effect of pre-task and on-line planning on learners' monologic oral production. The results indicated that pre-task planning enhanced grammatical complexity, lexical variation and fluency while on-line planning 
positively influenced accuracy and grammatical complexity. However, the pre-task planning led to more fluent and lexically varied language than the on-line planning and the language produced by the two planning group (pre-task planning and on-line planning) was equally grammatically complex. Additionally, the on-line planning led to more accurate language than pre-task planning. Mehrang and Rahimpour (2010) studied the effects of task structure and planning time on oral performance of EFL learners in terms of accuracy, fluency, and complexity of 64 upperintermediate learners of English as a foreign language. Results indicated that planning time had no effects on the accuracy and fluency of the learner performance. However, it led to more complex performances when participants performed the unstructured, complex task.

\section{E. Task Complexity and Its Justification}

Rahimpour (2002) lists three theoretical frameworks for task complexity. According to him, the theoretical framework for the proposed task complexity is based on research into first language acquisition (e.g., Brown and Bellugi, 1964), research findings from second language development (Meisel, 1987), and functional linguistic theory (Givon, 1989).

Robinson (2001) defines task complexity as:

Task complexity is the result of the attentoional, memory, reasoning, and other information processing demands imposed by the structure of the task to the language learner. These differences in information processing demands, resulting from design characteristics, are relatively fixed and invariant (p.29).

Robinson (2001) attributes the complexity of the task into three factors including inherent characteristics of the task itself which is related to the nature of input, the task conditions, and the processing operations involved in completing the tasks and the outcome that is required. These factors according to Robinson (2001) come under the heading of task complexity. The complexity of a task is the valid criteria to be taken into account in designing a task and syllabus. The design of a syllabus requires that the content be sequenced in a way so as to facilitate maximum learning (Ellis, 2003, 2008; Nunan, 1989; Robinson, 2001; 2007). In effect, this requires determining the complexity of individual tasks so that tasks can be matched to learners' level of development, this argument is in line with teachability and learnability hypothesis proposed by Pienemann (1985).

\section{F. Models of Task Complexity}

Different models of task complexity have been proposed by different researchers (Anderson and Lynch, 1988; Brindley, 1987; Brown and Yule, 1983; Candlin, 1987; Long, 1985; Prabhu, 1987; Rahimpour, 1997, 1999, 2002; Robinson 2001, 2007).

Among these models the present study was based on Robinson's Triadic Framework of Task Complexity or Cognition Hypothesis (2001, 2007). This framework distinguishes three task components: task complexity, task conditions, and task difficulty. Robinson (2001) pointed out that the development of theoretically motivated, empirically substantiable, and pedagogically feasible sequencing criteria has long been acknowledged as a major goal of research aimed at operationalizing task-based approaches to syllabus design. To this end, he proposed distinctions between cognitively defined task complexity, learner perceptions of task difficulty, and the interactive conditions under which tasks are performed. Robinson (2001, p.29) strongly argued that Task Complexity is the result of the attentional, memory, reasoning, and other information processing demands imposed by the structure of the task on the language learner. These differences in information processing demands, resulting from design characteristics, are relatively fixed and invariant. Task complexity will aid to explain within learner variance when performing any two tasks. It is, also, argued that the cognitively simpler tasks will involve a lower error rate, and/or be completed faster.

\section{G. Task Complexity Studies}

Some studies have been conducted to investigate task complexity and its effects on L2 learners' oral and written task performance in terms of accuracy, fluency, and complexity (Robinson, 2001, 2007; Gilabert, 2005; Ishikawa, 2006; Kuiken and Vedder, 2007, 2008; Rahimpour, 2007; Kim, 2009; Hosseini and Rahimpour, 2010, Salimi et al, 2011; Salimi and Dadashpour, 2010, 2012). Robinson (2001) found that complex tasks elicited less fluent, but more accurate and complex production than the simple tasks. Rahimpour (2007) studied the effect of task complexity on L2 learners' oral performance. The results showed that there-and-then task (complex task) led to more accuracy while here-and-now task (simple task) led to more complexity. In terms of fluency, here-and-now task led to more fluency than there-andthen task. Hosseini and Rahimpour (2010) investigated the effects of task complexity on L2 learners' written performance on narrative pictorial tasks of here-and- now and there-and- then. The results of the study demonstrated that cognitively more demanding task (there-and- then) were more fluent, but no significant effects on written narratives were observed on measures of accuracy and complexity. Salimi et al (2011) investigated the effect of task complexity on L2 learners' written performance. They found out that task complexity did not have a significant effect on accuracy. Regarding fluency of written production, they reported that task complexity had a significant effect on fluency of the learners. For complexity of written production, they found that L2 learners' written complexity was significantly affected by task complexity. That is, Complex task led to the production of more complex language in terms of syntactic mode. 
After reviewing the results of the previous studies conducted on planning time and task complexity, it was revealed that planning time, especially strategic planning time, and task complexity and their joint effects on L2 learners' oral/written performance have rarely been explored in the literature and there is a gap in the literature on this topic. Therefore, the present study set out to investigate the effects of strategic pre-task planning and task complexity on L2 learners' written performance in terms of accuracy.

\section{RESEARCH QUESTION AND HYPOTHESES}

On the basis of the above literature review, the present study aimed at investigating the following research question and research hypotheses:

RQ1: What are the effects of task complexity and strategic planning time on L2 learners' written performance in terms of accuracy?

HO: There isn't any significant difference between task complexity and planning time and L2 learners' written performance in terms of accuracy.

H1: Strategic planning group while performing a simple task will produce more accurate written production than unplanned group.

H2: Strategic planning time group while performing complex task will produce more accurate written production than unplanned group.

\section{Methodology}

\section{A. Participants}

The participants of the study were 50 English language learners with intermediate level of proficiency. They were both male and female attending a conversation course in a language institute in Iran. They aged between 17 and 30 . The participants were from Turkish language background and had taken classes in which speaking and listening activities were common. To ensure about their homogeneity and their proficiency level, a pre-test was administered to the students of the intermediate level. The participants of this study were selected randomly on the basis of their performance on the pre-test. Then, they were randomly assigned into two groups namely planned and unplanned groups.

\section{B. Data Collection Instrument}

In order to collect the data for this study, two versions of the same decision-making valid task (one simple and the other complex task) were taken from Gilabert (2007) and Salimi and Dadashpour (2012). A simplified 'fire chief' task used in cognitive psychology was utilized. In this task, learners are presented with a building where a fire has broken out and where a number of people need to be rescued. The problem in the complex version required learners not just one decision, but a long series, in which early decisions condition later ones. In both versions of the task, the learners were instructed to specify the actions they would take, determine the sequences of their actions, and justify their choice for actions and specific sequence. In the simple task, there are similar types of people (i.e. people with no particular roles) in the building who were faced with similar degrees of danger; the fire being relatively static, the smoke blowing away from the building. In the complex one, learners have to deal with specific types of people (e.g. a pregnant woman, an elderly man, an injured person, a hero).

\section{Procedure}

The data for this study was collected in two phases. First, the participants were asked to perform on the simple version of the decision-making task. In this phase, the planned group was asked to perform on the task with 10 minutes for strategic planning. Then, they were asked to perform on the task and write an essay. The participants of the other group, i.e. unplanned group, were asked to perform on the same task but they were not given any time for planning. After performing on the simple version of the task, the participants of both groups were asked to perform on the complex version of the decision-making task. Of course, it should be noted that the participants performed on the complex version of the task after two weeks. This interval of two weeks was due to eliminating the memory effects. In this phase, the participants of planned group, like the simple task, were given 10 minutes for strategic planning. Then, they were given the complex version of the task and were asked to perform on it. That is, they were asked to write an essay. Then, the unplanned group's participants were asked to perform on the complex version of decision making task; however, they were not given any time for strategic planning and were asked to write an essay. All the participants of both groups were given 40 minutes to perform the task.

\section{Accuracy Measure}

The number error-free T-units per T-units (Arent, 2003; Rahimpour, 2008). T-unit is defined as "the main clauses plus subordinate clauses attached to or embedded in them" and error-free T-units are those T-units that contain no grammatical, lexical, or spelling errors.

\section{Data Analysis And Results}


Table 1 clearly presents the means differences of accuracy of the written performance in simple task with and without strategic planning.

TABLE 1

COMPARISON OF THE MEANS OF ACCURACY OF WRITTEN PERFORMANCE IN PlanNED AND UNPLANNED SimPLE TASK

\begin{tabular}{|l|l|l|l|l|}
\hline & N & Mean & Std. Deviation & Std. Error Means \\
\hline Planned Accuracy Simple & 25 & $\mathbf{0 . 5 8 2 8}$ & $\mathbf{0 . 1 6 9 3 0}$ & $\mathbf{0 . 0 3 3 8 6}$ \\
\hline Unplanned Accuracy Simple & 25 & $\mathbf{0 . 3 9 0 8}$ & $\mathbf{0 . 1 1 4 9 2}$ & $\mathbf{0 . 0 2 2 9 8}$ \\
\hline
\end{tabular}

According to this table, the learners produced more accurate $(0.58)$ language with strategic planning in simple task than without strategic planning (0.39).

Figure 1 shows the means differences of accuracy with and without strategic planning in simple task.

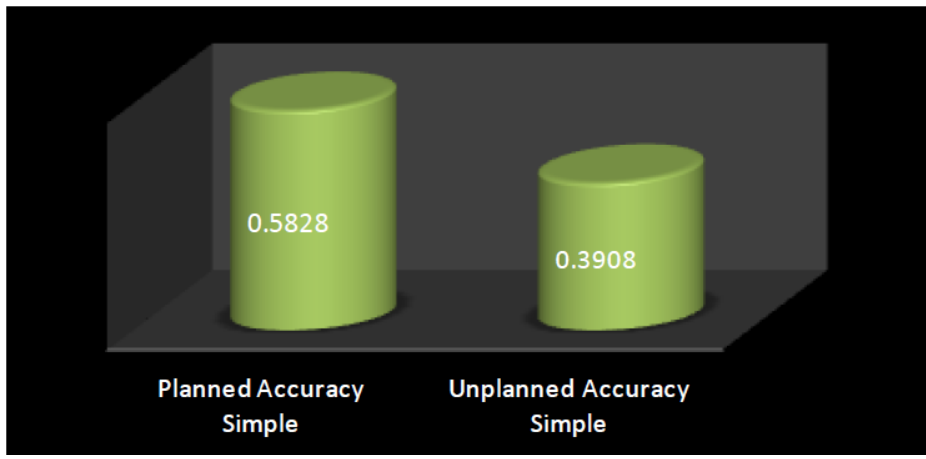

Figure 1. Comparison of the Means of Accuracy of Written Performance in Planned and Unplanned Simple Task

Table 2 shows the results of Independent Samples T-test for the means of accuracy of written performance of both groups in simple task.

TABLE. 2

INDEPENDENT SAMPLES T-TEST FOR THE MEANS OF ACCURACY OF WRITTEN PERFORMANCE IN PLANNED AND UNPLANNED SiMPLE TASK

\begin{tabular}{|c|c|c|c|c|c|c|c|c|c|}
\hline & \multicolumn{2}{|c|}{$\begin{array}{l}\text { Levene's Test for } \\
\text { Equality of } \\
\text { Variances }\end{array}$} & \multicolumn{7}{|c|}{ t-test for Equality of Means } \\
\hline & \multirow[t]{2}{*}{$\mathbf{F}$} & \multirow[t]{2}{*}{ Sig. } & \multirow[t]{2}{*}{$\mathbf{t}$} & \multirow[t]{2}{*}{ df } & \multirow[t]{2}{*}{$\begin{array}{l}\text { Sig. }(2- \\
\text { tailed) }\end{array}$} & \multirow[t]{2}{*}{$\begin{array}{l}\text { Mean } \\
\text { Difference }\end{array}$} & \multirow[t]{2}{*}{$\begin{array}{l}\text { Std. Error } \\
\text { Difference }\end{array}$} & \multicolumn{2}{|c|}{$\begin{array}{l}95 \% \text { Confidence } \\
\text { Interval of the } \\
\text { Difference }\end{array}$} \\
\hline & & & & & & & & Lower & Upper \\
\hline $\begin{array}{l}\text { Equal variances not } \\
\text { assumed }\end{array}$ & 4.353 & 0.042 & 4.692 & 42.244 & .000 & .19200 & .04092 & .10943 & 4.692 \\
\hline
\end{tabular}

Table 2 shows the results of statistical analysis of applying Independent Samples T-test to test the first hypothesis. The results of SPSS at $\mathrm{df}=48$ and $\alpha=.05$, suggested that there was a significant difference between strategic planning and L2 learners' accuracy in simple task. As a result, the first hypothesis claiming "strategic planning group while performing a simple task will produce more accurate written production than unplanned group" is confirmed.

Table 3 shows the means differences of accuracy of written performance of the participants in complex task with and without strategic planning.

TABLE 3

Comparison of the Means of ACCuracy of Written Performance in Planned and UnPlanned Complex Task

\begin{tabular}{|l|l|l|l|l|}
\hline & N & Mean & Std. Deviation & Std. Error Means \\
\hline Planned Accuracy Complex & 25 & $\mathbf{0 . 4 4 1 2}$ & $\mathbf{0 . 1 0 6 5 1}$ & $\mathbf{0 . 0 2 1 3 0}$ \\
\hline Unplanned Accuracy Complex & 25 & $\mathbf{0 . 3 4 8 8}$ & $\mathbf{0 . 0 7 6 7 2}$ & $\mathbf{0 . 0 1 5 3 4}$ \\
\hline
\end{tabular}

The data presented in table 3 shows that the participants of planned group produced more accurate $(0.44)$ language than unplanned group in complex task (0.34).

Figure 2 also shows the means differences of accuracy for planned and unplanned groups in complex task. 


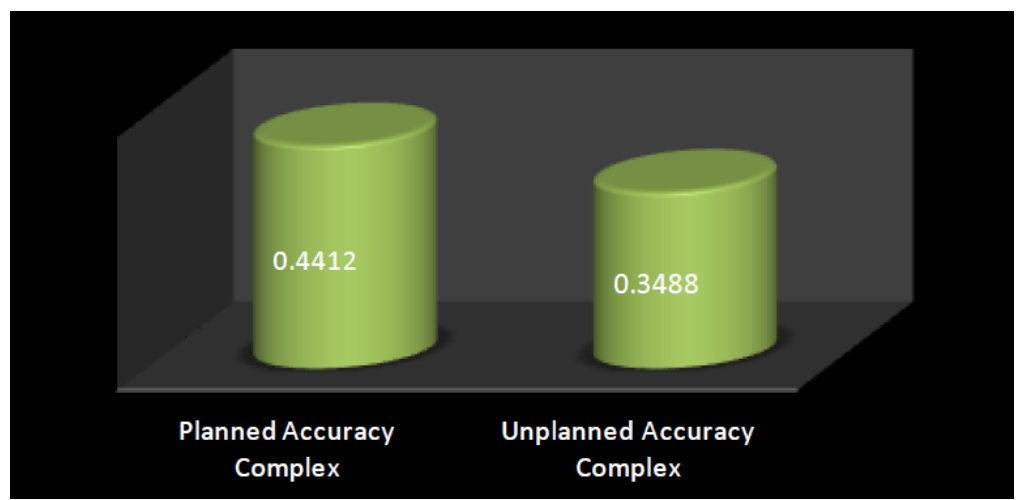

Figure 2. Comparison of the Means of Accuracy of Written Performance in Planned and Unplanned Complex Task

Table 4 shows the results of Independent Samples T-test for the means of accuracy of written performance of both groups in complex task.

TABLE 4

INDEPENDENT SAMPLES T-TEST FOR THE MEANS OF ACCURACY OF WRITTEN PERFORMANCE IN PLANNED AND UNPLANNED COMPLEX TASK

\begin{tabular}{|c|c|c|c|c|c|c|c|c|c|}
\hline & \multicolumn{2}{|c|}{$\begin{array}{l}\text { Levene's Test } \\
\text { for Equality of } \\
\text { Variances }\end{array}$} & \multicolumn{7}{|c|}{ t-test for Equality of Means } \\
\hline & \multirow[t]{2}{*}{$\mathbf{F}$} & \multirow[t]{2}{*}{ Sig. } & \multirow[t]{2}{*}{$\mathbf{t}$} & \multirow[t]{2}{*}{ df } & \multirow{2}{*}{$\begin{array}{l}\text { Sig. } \\
(2- \\
\text { tailed })\end{array}$} & \multirow{2}{*}{$\begin{array}{l}\text { Mean } \\
\text { Differenc } \\
\text { e }\end{array}$} & \multirow[t]{2}{*}{$\begin{array}{l}\text { Std. Error } \\
\text { Difference }\end{array}$} & \multicolumn{2}{|c|}{$\begin{array}{l}95 \% \text { Confidence Interval } \\
\text { of the Difference }\end{array}$} \\
\hline & & & & & & & & Lower & Upper \\
\hline $\begin{array}{l}\text { Independent } \\
\text { Samples Test }\end{array}$ & \multirow[b]{2}{*}{2.391} & \multirow[b]{2}{*}{0.129} & 3.520 & 48 & 0.001 & 0.09240 & 0.02625 & .03962 & 0.14518 \\
\hline $\begin{array}{l}\text { Equal variances } \\
\text { not assumed }\end{array}$ & & & 3.520 & 43.622 & 0.001 & 0.09240 & 0.02625 & .03948 & 0.14532 \\
\hline
\end{tabular}

Table 4 shows the results of statistical analysis of applying Independent Samples T-test to test the fourth hypothesis. The results of SPSS at $\mathrm{df}=48$ and $\alpha=.05$, revealed that there was a slight difference between strategic planning and L2 learners' accuracy in complex task. Thus, the second hypothesis claiming "strategic planning time group while performing complex task will produce more accurate written production than unplanned group" is confirmed.

\section{DISCUSSION}

Regarding the effects of strategic planning time and task complexity on L2 learners' written production in terms of accuracy in simple task, it was revealed that strategic planning in simple task led to more accuracy. That is, the participants who performed simple task with strategic pre-task planning produced more accurate language than the participants who performed simple task without strategic pre-task planning. Thus, our first hypothesis is confirmed. The findings of the study in terms of accuracy are in agreement with the findings of studies like Foster and Skehan (1996), Ortega (1999), Tavakoli and Skehan (2005), and Ishikawa (2006). However, the findings of the present study in terms of accuracy ran against the findings of the studies like Gilabert (2005), Mehrang and Rahimpour (2010), Hosseini and Rahimpour (2010), and Salimi and Dadashpour (2012). These findings in terms of accuracy can be interpreted in Levelt's (1989) terms, this result in a lighter processing load for the Conceptualizer and more "space" for the Formulator to work within. The Formulator can give more attention to grammatical accuracy, and performance is subsequently more accurate.

Regarding the effects of strategic planning and task complexity on L2 learners' written production in terms of accuracy in complex task, the findings of the study and the results of data analysis provided in table 4 and figure 2 , it was revealed there was a slight difference between strategic planning and written accuracy of learners in complex task. The findings of the study in terms of accuracy are in agreement with the findings of studies like Foster and Skehan (1996), Foster (1997), Ortega (1999), Tavakoli and Skehan (2005), and Ishikawa (2006). However, the findings of the present study in terms of accuracy ran against the findings of the studies like Gilabert (2005), Mehrang and Rahimpour (2010), Hosseini \& Rahimpour (2010), and Salimi and Dadashpour (2012). The higher rate of accuracy can be interpreted in terms of Long's view (1985) that a difficult task will lead learners to stretch their interlanguage resources. The accuracy can also be interpreted in terms of Givon's (1989) pragmatic and syntactic modes demanding learners to use greater syntactic resources and abilities which will lead to an increase in grammatical accuracy. The accuracy can also be attributed to the decreased cognitive load of attention paid by the learners to the difficult task than paid to the easy task under planned condition. The results of the study regarding the effects of planning time on both simple and complex task proved the positive effects of provision of planning time on L2 learners' written task performance. 


\section{PeDAGOGiCAL IMPLiCATIONS}

This study carries some implications for second language acquisition (SLA) researchers, language teachers, and syllabus designers. It also provides insights on designing and implementation of tasks in L2 classroom settings. As mentioned earlier, one of the major issues regarding task-based language teaching and learning is to find out how learners allocate attention between the competing goals of fluency, accuracy and complexity and therefore, establish a balance between these performance areas. So, the findings make it possible for a teacher or more importantly for a syllabus designer to design sequences of instructional activities that alternate attention to each of the areas so that the goal of balanced development can be obtained. Also, the findings of this study can contribute to task-based teaching methodology since planning is considered as one of the task implementation factors that can be manipulated by giving chance or not providing time for planning, offering different types of planning to the learners in task performance, and providing learners with various lengths of planning time and planning effects can be observed in the performance of language learners (Ellis, 2009). These findings may also add to the present literature in SLA theory, language testing, syllabus design, and material development.

\section{REFERENCES}

[1] Anderson, A. and Lynch, T. (1988). Listening. Oxford: Oxford University Press.

[2] Arent, R. (2003). Promoting revision and development in L2 writing through a combination- based curriculum. The Korea TESOL Journal, 6(1), 1-26.

[3] Breen, M. P. (2001). Syllabus design. In R. Carter and D. Nunan (Eds.), The Cambridge guide to teaching English to speakers of other languages (pp.151-159). Cambridge: Cambridge University Press.

[4] Brindley, J. (1987). Factors affecting task difficulty. In D. Nunan, (Ed.), Guidelines for the development of curriculum resource (pp.45-56). Adelaide: National Curriculum Resource Center.

[5] Brown, R., and Bellugi, U. (1964). 'Three processes in the child's acquisition of syntax'. Harvard Educational Review, 34, 133151.

[6] Brown, G., and Yule, G. (1983). Teaching the spoken language: an approach based on the analysis of conversational English. Cambridge: Cambridge University Press.

[7] Bygate, M. (2001). Effects of task repetition on the structure and control of language. In M. Bygate, P. Skehan, and M. Swain (Ed.), Researching pedagogic tasks: Second language learning, teaching and testing (pp. 23 - 48). London: Longman.

[8] Bygate, M., Skehan, P. and Swain, M. (2001). 'Introduction' in M.Bygate, P. Skehan and M. Swain (Eds.). Researching pedagogic tasks, second language learning, teaching and testing. Harlow: Longman.

[9] Candlin, C. (1987). Towards task-based language learning. In Candlin, C. \& Murphy, D. (Eds.), Language Learning Tasks (pp.5-22). Englewood Cliffs, NJ: Prentice Hall.

[10] Crookes, G. (1989). Planning and interlanguage variation. Studies in Second Language Acquisition, 11, $367-383$.

[11] Dadashpour, S. (2011). The Effects of Task Complexity on EFL Learners' Written Performance. Unpublished master's thesis, Islamic Azad University, Maragheh Branch, Maragheh, Iran.

[12] Das, J. P., Kar, B. C., and Parrilla, R. K, (1996). Cognitive planning: the psychological basis of intelligent behavior. New Delhi: Sage.

[13] Ellis, R. (1987). Interlanguage variability in narrative discourse: Styles shifting in the use of past tense. Studies in Second Language Acquisition, 9, 1-20.

[14] Ellis, R. (2003). Task-based language learning and teaching. Oxford: Oxford University Press.

[15] Ellis, R (Ed.) (2005). Planning and task performance in a second language. Amsterdam: John Benjamins .

[16] Ellis, R. (2008). The study of second language acquisition. Oxford: Oxford University Press.

[17] Ellis, R. (2009). Task-based language teaching: Sorting out the misunderstandings. International Journal of Applied Linguistics 19 (3), 229-246.

[18] Gilabert, R. (2005). Task complexity and L2 narrative oral production. Unpublished Ph.D. dissertation. University of Barcelona Spain.

[19] Gilabert, R. (2007). Effects of manipulating task complexity on self-repairs during L2 oral production. International Review of Applied Linguistics, 45, 215-240.

[20] Givon, T. (1979). On understanding grammar. New York: Academic Press.

[21] Givon, T. (1989). Mind, code, and context. essays in pragmatics. Hillsdale, NJ: Erlbaum.

[22] Hosseini, P. and Rahimpour, M. (2010). The Impact of Task Complexity on L2 Learners' Written Narratives, CCSE, 3 (3), 198205.

[23] Ishikawa, T. (2006). The effects of task complexity and language proficiency on task-based language performance. The Journal of Asia TEFL, 3(4), 193-225.

[24] Kim, Y. (2009). The effects of task complexity on learner-learner interaction. System, 37,254-268.

[25] Kuhi, D., Salimi, A. and Shafaei, A. (2012). The effect of generic features of task on L2 learners' oral performance. Theory and Practice in Language Studies, 2 (4), 820-825

[26] Kuiken, F., and Vedder, I. (2007). Task complexity and measures of linguistic performance in L2 writing. International Review of Applied Linguistics, 45(3), 261-284.

[27] Kuiken, F., and Vedder, I. (2008). Cognitive task complexity and written output in Italian and French as a foreign language. Journal of Second Language Writing, 17, 48-60.

[28] Levelt, W. (1989). Speaking: From intension to articulation. Cambridge MA: The MIT Press.

[29] Long, M. (1985). A role for instruction in second language acquisition: task-based language teaching. In K. Hyltenstam and M. Pienemann (Eds.), Modelling and assessing second language acquisition (pp.77-99). Clevedon: Multilingual Matters. 
[30] Long, M. (Ed.) (2007) . Problems in SLA, Mahwah, NJ: Erlbaum.

[31] Long, M., and Crookes, G. (1992). Three approaches to task-based syllabus design. TESOL Quarterly, 26(1), $27-56$.

[32] Mehrang, F., and Rahimpour, M. (2010). The impact of task structure and planning conditions on oral performance of EFL learners. Procedia Social and Behavioral Sciences: World Conference on Educational Sciences 2010, Istanbul, Turkey.

[33] Meisel, J. (1987). Reference to past events and actions in the development of natural language acquisition. In C. Pfaff (Ed.), First and second language acquisition processes (pp.206-224). Cambridge, MA: Newbury House.

[34] Newell, A. and H. Simon. (1972). Human problem solving. Englewood Cliffs, NJ: Prentice Hall.

[35] Nunan, D. (1989). Designing tasks for the communicative classroom. Cambridge: Cambridge University Press.

[36] Ochs, E. (1979). Planned and unplanned discourse. In Givon, T.(Ed.). Syntax and Semantics. New York: Academic Press, 5180.

[37] Ortega, L. (1995). The effect of planning in L2 Spanish oral narratives. Studies in Second Language Acquisition, 21,108 - 148.

[38] Ortega, L. (1999). Planning and focus on form in L2 oral performance. Studies in Second Language Acquisition, 21, 109-148.

[39] Ortega, L. (2005). What do learners plan? Learner-driven attention to form during pretask planning. In Ellis, R. (Ed.) Planning and task performance in a second language. Amsterdam: John Benjamins.

[40] Pieneman, M. (1985). 'Learnability and syllabus construction in K. Hyltenstam and M. Pienemann (eds.): Modeling and Assessing Second Language Acquisition. Clevedon, Avon: Multilingual Matters.

[41] Prabhu, N. S. (1987). Second language pedagogy. Oxford: Oxford university press.

[42] Rahimpour, M. (1997). Task complexity, task condition, and variation in L2 oral discourse. Unpublished Ph.D. thesis, University of Queensland, Australia.

[43] Rahimpour, M. (1999). Task complexity and variation in interlanguage. In N. O. Jungheim\&P. Robinson (Eds.), Pragmatic and pedagogy: proceeding of the $3^{\text {rd }}$ pacific Second Language Research Forum (pp.115-134). Tokyo, Japan: Pac LRF.

[44] Rahimpour, M. (2002). Factors affecting task difficulty. Journal of the Faculty of Literature and Humanities, Tarbiat Moallem University, 9(33), 1-16.

[45] Rahimpour, M. (2007). Task complexity and variation in L2 learners' oral discourse. Working Papers in Language and Linguistics, University of Queensland, 1-9.

[46] Rahimpour, M. (2008). Implementation of task-based approaches to language teaching. Pazhuhesh-e-Zabanha-ye Khareji Journal, University of Tehran, 41, 45-61.

[47] Rahimpour, M. (2010). Current trends on syllabus design in FL instruction. Procedia Social and Behavioral Sciences, 2, 166064.

[48] Robinson, P. (1995). Task complexity and second language narrative discourse. Language Learning, 45(1), 99-140.

[49] Robinson, P. (2001). Task complexity, task difficulty, and task production: exploring interactions in a componential framework, Applied Linguistics, 22(1), 27-57.

[50] Robinson, P. (2003). The cognition hypothesis, task design, and adult task-based language learning. Second Language Studies, 21(2), 45-105.

[51] Robinson, P. (2005). Cognitive complexity and task sequencing: studies in a componential framework for second language task design. International Review of Applied Linguistics, 43, 1-32.

[52] Robinson, P. (2006). Criteria for classifying and sequencing pedagogic tasks. In M. P. G. Mayo (Ed.), Investigating tasks in formal language learning, (pp. 7 - 26).Clevdon: Multilingual Matters.

[53] Robinson, P. (2007). Triadic framework for TBLT: Task complexity, task difficulty, and task condition. The Journal of Asia TEFL, 195-225

[54] Salimi, A. and Dadashpour, S. (2010). Task complexity and L2 learners' written performance. A paper presented at WCCES 14. Bogazici University, Istanbul, Turkey, 14-18 June.

[55] Salimi, A. and Dadashpour, S. (2012a). Task Complexity and Language Production Dilemmas (Robinson's Cognition Hypothesis vs. Skehan's Trade-off Model). Procedia-Social and Behavioral Sciences, 46, 643-652.

[56] Salimi, A. and Dadashpour, S. (2012b). Task Complexity and SL development: Does task complexity matter?. Procedia-Social and Behavioral Sciences, 46, 726-735.

[57] Salimi, A, Dadashpour, S. and Asadollahfam, H. (2011). The effect of cognitive task complexity on EFL learners' written production. Procedia-Social and Behavioral Sciences, 29, 1390-1399.

[58] Salimi, A., Shafaei, A. and Kuhi, D. (2012). The Impact of the generic features of tasks on L2 learners' written production. Procedia-Social and Behavioral Sciences, 46, 653-662.

[59] Salimi, A. and Yusefi, M. (2009). The effect of task complexity on L2 learners' uptake in EFL context. A paper presented at $7^{\text {th }}$ International TELLSI Conference. University of Yazd, October, 20-22.

[60] Sangarun. J. (2001). The effects of pre-task planning on foreign language performance. Doctoral thesis, University of Toronto, Canada.

[61] Sangarun, J. (2005). The effects of focusing on meaning and form in strategic planning. In Ellis, R. (Ed.) Planning and task performance in a second language. Amsterdam: John Benjamins.

[62] Schmidt, R. (2001). Attention. In Robinson, P. (Ed.), Cognition and second language instruction. Cambridge: Cambridge University Press.

[63] Shafaei, A. (2012). The effect of generic features of task on L2 learners' oral performance in EFL context. Unpublished master's thesis, Islamic Azad University, Maragheh Branch, Maragheh, Iran.

[64] Skehan, P. (1996). A framework for the implementation of task-based instruction. Applied Linguistics, 17(1), 38-62.

[65] Skehan, P. and P. Foster (1997). Task type and task processing conditions as influences on foreign language performance. Language Teaching Research 1: 185-211.

[66] Skehan, P. and Foster, P. (1999). The influence of task structure and processing conditions on narrative retellings. Language Learning, 49(1), 93-120.

[67] Tavakoli, P., and Foster, P. (2008). Task design and second language performance: the effect of narrative type on learner output. Language Learning, 58(2), 439-473. 
[68] Tavakoli, p., and Skehan, P. (2005). Strategic planning, task structure, and performance testing. In R. Ellis (Ed.), Planning and task performance in a second language (pp. 239 -277). Amsterdam: Benjamins.

[69] Wigglesworth, G. (1997). An investigation of planning time and proficiency level on oral test discourse. Language Testing, 14, 85-106.

[70] Willis, D., and Willis, J. (2001). Task-based language learning. In R. Carter and D. Nunan (Eds.), The Cambridge guide to teaching English to speakers of other languages (pp.173-179). Cambridge: Cambridge University Press.

[71] Yuan, F. (2001). The effects of planning on language production in task-based language teaching. Doctoral thesis, Temple University.

[72] Yuan, F., and Ellis, R. (2003). The effects of pre-task planning and on-line planning on fluency, complexity and accuracy in L2 monolgic oral production. Applied Linguistics, 24 (1), 1-27.

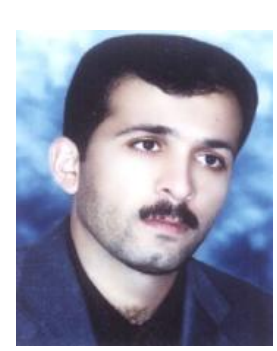

Asghar Salimi is a PhD candidate in applied linguistics at the University of Tabriz. He has been teaching English for over 10 years. He is currently a faculty member of Maragheh University. He has presented and published more than ten papers in different national and international conferences and journals in different countries. His main areas of interest are task-based learning and teaching, syllabus design, and Second Language Acquisition (SLA).

Parviz Alavinia got his PhD in TEFL/TESOL from Allameh Tabataba'i University in Tehran, Iran, 2010, his MA (in the same major) from The University for Teacher Training in Tehran, Iran, 2004, and his BA degree from Urmia University, Urmia, Iran, 2001. $\mathrm{He}$ is currently involved as a full-time assistant professor and staff member at Urmia University. His main areas of interests include psycholinguistics, philosophy of language, critical discourse analysis, task-based instruction, and particularly emotional intelligence.

Parvin Hosseini is M.A in TEFL. She received her degree from Islamic Azad University, Urmia Branch, Urmia, Iran. Her main areas of interest are task-based language teaching and planning time. 